\title{
Efficient Mitochondrial Genes in the Characterization of Meat Species Applying PCR-RFLP'Technique
}

\author{
Walaa M.H. Farag ${ }^{1}$, Samira H. Aljuaydi ${ }^{1}$, Mona K. Galal ${ }^{1}$, Gehan M.A Kassem ${ }^{2}$, Eman M. \\ GOUDA $^{1 *}$
}

${ }^{1}$ Department of Biochemistry and Molecular Biology, Faculty of Veterinary Medicine, Cairo University, Giza, Egypt; ${ }^{2}$ Department of Meat Hygiene, Food Hygiene and Control, Faculty of Veterinary Medicine, Cairo University, Giza, Egypt.

\begin{abstract}
Identification of meat and meat mixture has a substantial role either economically, on religious side, or public health concern. This study focused on the application of the PCR-RFLP technique to differentiate between mixtures of different animal species in raw and cooked meat. Animal species meat mixtures used in the present study were beef, donkey, dog, poultry meat, and mechanical deboned meat (MDM). The amplification of the required region of mitochondrial genes, $12 \mathrm{~S}$ rRNA gene, $16 \mathrm{~S}$ rRNA gene, and cytochrome $b$ (Cyt- $b$ ) gene using pairs of universal primers were done by PCR. Restriction fragment length polymorphism (RFLP) was done by subsequently digesting the amplified PCR product using two restriction endonucleases (AluI and HinfI). All species and mixtures at different ratios could be discriminated using the two restriction enzymes giving rise to distinct banding patterns on an agarose gel. The cooking of different mixtures affects the banding number in the 12S rRNA and cytochrome $b$ (Cyt- $b$ ) gene. The $12 \mathrm{~S}$ rRNA, $16 \mathrm{~S}$ rRNA genes, and Cyt- $b$ genes of mitochondrial genome using PCR-RFLP method may be used for identification of meat mixtures.
\end{abstract}

Keywords | Mitochondrial genes, MDM, Cooked meat, PCR-RFLP, Meat mixture

Received | August 23, 2021; Accepted | November 02, 2021; Published | December 01, 2021

*Correspondence | Eman M. Gouda, Department of Biochemistry and Molecular Biology, Faculty of Veterinary Medicine, Cairo University, Giza, Egypt; Email: eman_gouda@cu.edu.eg

Citation | Farag WMH, Aljuaydi SH, Galal MK, Kassem GMA, Gouda EM (2022). Efficient mitochondrial genes in the characterization of meat species applying PCR-RFLP technique. Adv. Anim. Vet. Sci. 10(1): 8-13.

DOI | http://dx.doi.org/10.17582/journal.aavs/2022/10.1.8.13

ISSN (Online) | 2307-8316; ISSN (Print) | 2309-3331

Copyright (C) 2022 Farag et al. This is an open access article distributed under the Creative Commons Attribution License, which permits unrestricted use, distribution, and reproduction in any medium, provided the original work is properly cited.

\section{INTRODUCTION}

$\mathrm{F}$ ood authenticity has taken a significant concern and show increasing attention over the past decade because of the increasing complexity of food chains (E1 Sheikha et al., 2018). Food fraud is defined as an illegal deception that's mainly economically motivated (Spink et al., 2019b). Economically Motivated Adulteration (EMA) is defined as counterfeit addition of inauthentic substances or elimination or replacement of authentic substances without the buyer's knowledge for the economic gain of the vendor (Moore, 2011). Recently, EMA considered an issue of economic gain with potential health risk (Spink et al., 2019a). Meat and meat products are one among the food commodities that are most vulnerable to adulteration activity due to their relatively high value, complex supply chains especially concerning halal supply chain, and increase demand within the market (Downey, 2016). Adulteration in meat and meat products usually involves the substitution of high-price meat with less costly meat or non-meat ingredients (Downey, 2016). Besides the ruminant meat, poultry meat products are also frequently substituted with meat ingredients from similar species (Amaral et al., 2016). Poultry meat is one of the foremost extensively consumed meats within the world (Masole et al., 2015), and it covers a large range of species, like chicken, duck, turkey, goose, and pigeon (FAO, 2018). In the meat sector, the substitution of high-cost meats with low-cost alternatives, especially for those designated as Protected Designation of Origin (PDO) or Protected Geographical Indication (PGI), and 
therefore the mislabeling of meat species are significant issues (Fajardo et al., 2010; Gvozdanović et al., 2020). Mechanically deboned meat (MDM) is that a process of mechanical deboning that involves crushing the bones of beef, poultry, pork and mixing with meat and skin before the bone is separated. Inevitably, crushing of the animal's bones and tissues results in changes in chemical, physical, sensory and functional properties of the meat, and meat color. MDM production is done in two forms, high pressures; a fine-textured meat paste was the end-product, suitable to be used in cooked sausages. Low pressure produced a coarse tissue texture of superior quality meat that might not be distinguished from traditional minced meat (socalled $3 \mathrm{~mm}$ or Baader meat) (Tonder, 2020). Donkey meat products are highly nutritious; it's considerably costlier than other meats as a result of its low supply (Chen et al., 2015). In Islamic countries, donkey meat consumption is prohibited on religious grounds (Mousavi et al., 2015). Donkey meat could likely be mixed with other meat tissues for economic benefits and there's a desire to avoid donkey meat entering the food supply chain in Islamic countries (Kim et al., 2020). Enforcement procedures generally to insure that what consumers get on their tables are genuine and safe. In this regard the identification of the animal origin is crucial with relevancy to religious concerns and for public health. Although there are various national and international laws for supervising the standard and safety of meat and meat products, meat adulteration continues to be widespread (Zheng et al., 2019). Several molecular genetic approaches for meat authenticity and traceability based on DNA fingerprinting have been developed and widely used (Sajali et al., 2021; Hrbek et al., 2020; Murugaiah et al., 2015). PCR amplification techniques are the most common used in meat species identification providing more accuracy and reliability (Girish et al., 2005). PCRRFLP combined with universal primer has advantages of sensitivity and specificity used in many practices of meat discrimination (Tian et al., 2015; Erwanto et al., 2014; Huang et al., 2013). The present study was initiated with the goal to discriminate meat of different animal species under various processing conditions using PCR-RFLP technique with designed universal primers of $16 \mathrm{~S}$ rRNA,
12S rRNA and cytochrome $b$.

\section{MATERIALS AND METHODS}

\section{SAMPLING AND SAMPLE PREPARATION}

Pure meat samples of beef, dog, donkey, chicken species and mechanical deboned meat (MDM) were provided by Meat Hygiene department in the faculty of veterinary medicine, Cairo University. All collected samples were kept and stored at $-20^{\circ} \mathrm{C}$ till analysis. Samples prepared in two sets. The first set of pure meat samples. The second set was beef: donkey and beef: dog meat mixed samples prepared in ratio's 95:05, 90:10, and 85:15, 80:20 (w/w), Poultry: MDM mixed samples in ratio's 95:05, 90:10, and $85: 15,80: 20(\mathrm{w} / \mathrm{w})$. The second set was replicated with the same mixed ratio's, kept in thermoplastics bags and undergo cooking at $100{ }^{\circ} \mathrm{C}$ for one hour in boiling water. Then DNA extraction was applied after completing the weighing, mincing and cooking processes.

\section{DNA EXTRACTION, PRIMER DESIGNS AND PCR AMPLIFICATION}

DNA extracted and purified from the samples by using DNA extraction kit (GeneJet) Genomic DNA Purification Kit- lot 00508807- Thermo Scientific) using the protocol provided with the kit. Three sets of universal primers used in this study were, $12 \mathrm{~S}$ rRNA gene, $16 \mathrm{~S}$ rRNA gene and cytochrome $\mathrm{b}$ gene with amplicon length shown in Table 1. The primers were purchased from (Invitrogen by Thermo Fisher Scientific). PCR amplification reactions were performed for the extracted DNA. Each extracted DNA amplification reaction was set up in total volume of $25 \mu 1$. These reactions were subjected to a cycle conditions of 5 min at $95{ }^{\circ} \mathrm{C}$ initial denaturation followed by 35 cycles; each of which consisted of $95{ }^{\circ} \mathrm{C}$ for $45 \mathrm{~s}$ denaturation, for $45 \mathrm{~s}$ annealing for each primer as mention in Table 1 , and $72{ }^{\circ} \mathrm{C}$ for 45 s primer extension and final extension step at $72^{\circ} \mathrm{C}$ for $10 \mathrm{~min}$. The electrophoresis of PCR products were done on $2 \%$ agarose gel with ethidium bromide along with 50pb DNA ladder (Intron Biotechnology) and visualized under ultraviolet light in a trans- illuminator.

Table 1: The sequence of $12 \mathrm{~S}$ rRNA, $16 \mathrm{~S}$ rRNA, and Cyt- $b$ primers, product size of amplicons, optimum annealing temperatures.

\begin{tabular}{|c|c|c|c|c|}
\hline Target region & Gene sequence & $\begin{array}{l}\text { amplicon } \\
\text { bp }\end{array}$ & $\begin{array}{l}\text { Annealing } \\
\text { temp. }\end{array}$ & REF \\
\hline \multirow[t]{2}{*}{$12 \mathrm{~S}$ rRNA } & F: 5' - CAA ACT GGG ATT AGA TAC CCC ACT AT-3' & \multirow[t]{2}{*}{$440 \mathrm{bp}$} & \multirow[t]{2}{*}{$60^{\circ} \mathrm{C}$} & \multirow{2}{*}{$\begin{array}{l}\text { (Chen et al., } \\
\text { 2010) }\end{array}$} \\
\hline & R: 5' - GAG GGT GAC GGG CGG TGT GT 3' & & & \\
\hline \multirow[t]{2}{*}{$16 \mathrm{~S}$ rRNA } & F: 5' - CGC CTG TTT ATC AAA AAC AT - 3' & \multirow[t]{2}{*}{$600 \mathrm{bp}$} & \multirow[t]{2}{*}{$56^{\circ} \mathrm{C}$} & \multirow{2}{*}{$\begin{array}{l}\text { (Saikia.et al., } \\
\text { 2016) }\end{array}$} \\
\hline & R: 5' - CTC CGG TTT GAA CTC AGA TC - 3' & & & \\
\hline \multirow[t]{2}{*}{ Cyto b } & F: 5' - CCC CTC AGA ATG ATA TTT GTC CTCA-3' & \multirow[t]{2}{*}{$359 \mathrm{bp}$} & \multirow[t]{2}{*}{$54^{\circ} \mathrm{C}$} & \multirow{2}{*}{$\begin{array}{l}\text { (Murugaiah et } \\
\text { al., 2009) }\end{array}$} \\
\hline & R: 5' - CCA TCC AAC ATC TCA GCA TGA TGA AA -3' & & & \\
\hline
\end{tabular}


RESTRICTION FRAGMENT LENGTH POLYMORPHISM (RFLP)

PCR products of $12 \mathrm{~S}$ rRNA, 16S rRNA and Cyt- $b$ were subjected for digestion by restriction enzymes. Two restriction enzymes: ALuI (New England BioLabs) and HinfI (Enzynomics) were selected for digestion of amplified fragments. The digested products were analyzed on $2 \%$ agarose gel electrophoresis.

\section{RESULTS AND DISCUSSION}

\section{PCR AMPLIFICATION OF MITOCHONDRIAL (MT) GENES} Universal primers amplify the extracted DNA, resulting in PCR products of $12 \mathrm{~S}$ rRNA, $16 \mathrm{~S}$ rRNA genes and Cyt $-b \mathrm{mt}$ genes with size about 440bp, 600bp and 358bp, respectively.

\section{RESTRICTION FRAGMENT LENGTH POLYMORPHISM} ANALYSIS

The PCR-RFLP technique is of potential value, in precise identification of animal species. PCR products obtained of mitochondrial genes were subjected to digestion using restriction enzymes $A L u I$ and Hinfl, the fragmented patterns were subjected to agarose gel electrophoresis.

\section{RFLP PATTERNS IN PURE ANIMAL SPECIES}

Each animal species presented a specific RFLP pattern using both $A L u I$ and HinfI restriction enzymes. As shown in (Figure 1), For 12S rRNA, AluI digestion yielded in beef, dog and donkey two fragments and three fragments in poultry and MDM. While $16 \mathrm{~S}$ rRNA yielded in all pure meat samples two fragments exceptionally MDM sample showed three fragments pattern. Whereas, in cytochrome $b$ AluI digestion, generated one fragment in beef and $\mathrm{dog}$, two fragments in donkey, poultry and MDM. HinfI digestion of $12 \mathrm{~S}$ rRNA yielded in beef, dog and donkey two fragments and three fragments for poultry and MDM (Figure 2). 16S rRNA yielded two fragments in beef, dog, donkey, and MDM while for poultry showed only one fragment, whereas, cytochrome HinfI digestion generated one fragment in beef and dog but in donkey, poultry and MDM generated two fragments.

RFLP PATTERNS IN RAW AND COOKED MIXED SAMPLES PCR -RFLP using $A L u I$ and HinfI (Figures 3,4 ) showed a difference in banding pattern and density between cooked and raw mixed samples, by increasing these patterns in $12 \mathrm{~S}$ rRNA and 16S rRNA genes while decreasing in cytochrome $b$ gene, these results obtained by using cooking process, whereas raw mixed samples had no difference between different proportions of meat admixes used in $12 \mathrm{~S}$ rRNA and $16 \mathrm{~S}$ rRNA, while cyt- $b$ showed difference by decrease in number of bands using $A L u I$ in the mix of beef+donkey and poultry+MDM in ratio 95:05. But in case of using the technique with Hinfl we observed the small percent of mixed beef+donkey and poultry+MDM cannot be detected in mitochondrial $16 \mathrm{~S}$ rRNA and cyto-b, respectively.

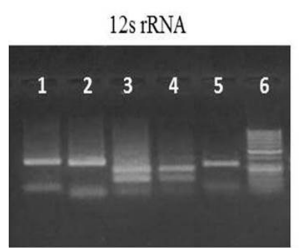

Lane 6: 50 bp DNA ladder, Lane 1: beef, Lane 2: donkey, Lane 3: poutry, Lane 4: MDM, Lane 5: dog

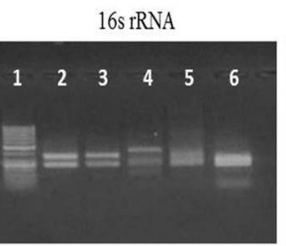

Lane 1: 50 bp DNA ladder, Lane 2: Lane 5: MDM, Lane 6: dog $\quad$ 8,9: dog, Lane 10,11: poutry
Figure 1: RFLP profile of mt. 12S rRNA, 16S rRNA and Cyt $-b$ genes. PCR amplicons of pure samples used in the present study that subjected to $A L u I$ restriction digestion.
$12 s+R N A$

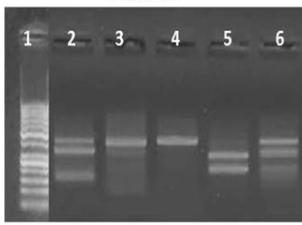

Lane 1: 50 bp DNA ladder, Lane 2: beef, Lane 3: donkey, Lane 4: dog Lane 5: pouttry and Lane 6: MDM

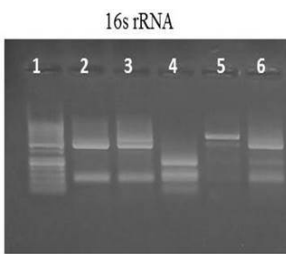

Lane 1: 50bp ladder, lane 2 : beef, lane $3: \operatorname{dog}$, lane 4 : donkey, lane 5 poultry lane 6: MDM.
Cytochrome

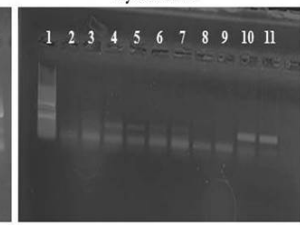

Lane 1: 50 bp DNA ladder, Lane 2, 3: beef, Lane 4, 5: MDM, Lane 6,7: donkey, Lane 8,9: dog, Lane 10,11: poutry
Figure 2: RFLP profile of mt. 12S rRNA, $16 \mathrm{~S}$ rRNA and Cyt- $b$ genes. PCR amplicons of pure samples used in the present study that subjected to HinfI restriction digestion.
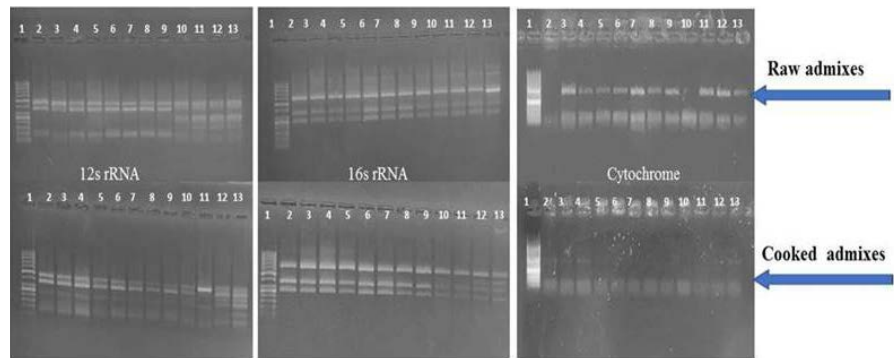

Lane 1: $50 \mathrm{bp}$ DNA ladder, Lane 2: beef + donkey $(95+5)$, Lane 3: beef + donkey $(90+10)$, Lane 4 : beef + donkey $(85+15)$, Lane $5:$ beef + donkey $(80+20)$, Lane $6:$ beef $+\operatorname{dog}(95+5)$, Lane $7:$ beef $+\operatorname{dog}$ $(90+10)$, Lane 8: beef $+\operatorname{dog}(85+15), \operatorname{Lane} 9:$ beef $+\operatorname{dog}(80+20)$, Lane $10:$ Poultry $+\mathrm{MDM}(95+5)$, Lane11: Poultry $+\mathrm{MDM}(90+10)$, Lane 12 : Poultry $+\mathrm{MDM}(85+15)$, Lane 13: Poultry $+\mathrm{MDM}$ $(80+20)$.

Figure 3: RFLP pattern of PCR Amplified mt. 12S rRNA, $16 \mathrm{~S}$ rRNA and Cyt- $b$ genes. Digested with restriction Enzyme $A L u l$ of raw and cooked admixed samples producing following restriction products.

Meat adulteration, mainly for the purpose of economic pursuit, is widespread and leads to serious public health risks and religious violations especially in developing countries (Soman et al., 2020). Beef is generally the most expensive meat in Egypt and thus, the cost of making beef meat balls is higher than for other types of meat. As a result, this has encouraged some sellers to adulterate beef meatballs with inferior or illegal meats to decrease the production cost and maximize profits. Recently, DNA-based methods have proved to be accurate, fast and sensitive method for meat authentication. 


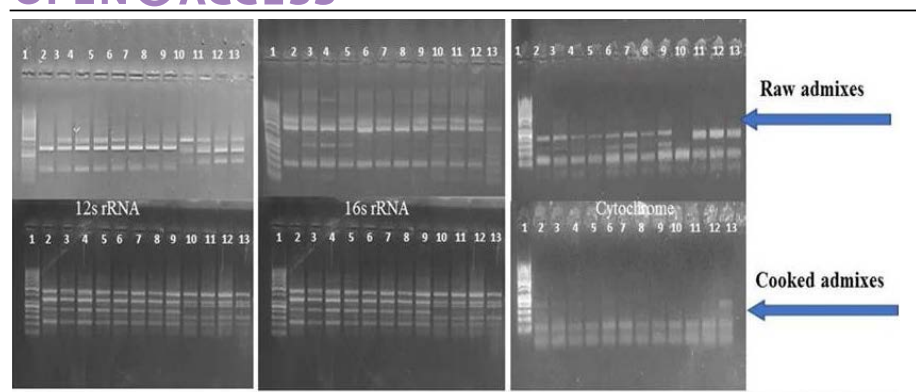

Lane 1: $50 \mathrm{bp}$ DNA ladder, Lane 2: beef + donkey $(95+5)$, Lane 3 : beef + donkey $(90+10)$, Lane $4:$ beef + donkey $(85+15)$, Lane 5 : beef + donkey $(80+20)$, Lane $6:$ beef $+\operatorname{dog}(95+5)$, Lane $7:$ beef $+\operatorname{dog}(90+10)$, Lane 8: beef $+\operatorname{dog}(85+15)$, Lane $9:$ beef $+\operatorname{dog}(80+20)$, Lane $10:$ Poultry $+\mathrm{MDM}(95+5)$, Lane11: Poultry + MDM $(90+10)$, Lane 12: Poultry + MDM (85+15), Lane 13: Poultry + MDM $(80+20)$.

Figure 4: RFLP pattern of PCR Amplified mt.12S rRNA, 16S rRNA and cyt- $b$ genes. Digested with restriction Enzyme Hinfl of raw and cooked admixed samples producing following restriction products.

Mitochondrial DNA genes may provide information about different meat species. The large variability of mt DNA targets as compared with nuclear sequences facilitates the discrimination of closely related animal species even in the case of mixtures of species (Prado et al., 2002). Mitochondrial DNA facilitates PCR amplification even in cases where the availability of DNA template after extraction is insufficient for detection (Murugaiah et al., 2009). Compared to nuclear DNA, mitochondrial DNA is protected by a double layer of mitochondrial membrane and better resists processing injury. Mitochondrial DNA undergoes several mutations within its sequences thus facilitating unique identification of different species (Kumar et al., 2015). The PCR-RFLP procedure appeared to be a simple, can be used with degraded DNA and easy method for routine analysis. It does not require preliminary sequencing of the investigated fragment. PCR-RFLP is a sensitive, accurate, and versatile method for meat authenticity verification (Rashid et al., 2015) simpler and time saving than real-time PCR (Ali et al., 2011). In the present study, PCR-RFLP method with a specific primer has been successfully used to amplify $12 \mathrm{~S}$ rRNA, $16 \mathrm{~S}$ rRNA and $\mathrm{Cyt}-b$ genes from different meat species at various levels of adulteration. Beef, donkey, dog, poultry, and MDM in various combinations with different percentage up to $5 \%$ concentration of admix meat in row and cooked meat mixture could be discriminated using conventional PCR followed by RFLP technique for mitochondrial DNA. The meat balls adulteration was detected to as low as 5\% concentration of admix. Rahman et al. (2015) used PCRRFLP coupled with a lab-on-a-chip detection platform to detect dog meat in burger formulations using $\mathrm{Cyt}-b$ gene in chicken and beef burgers. Doosti and Coworkers (2014) used PCR-RFLP coupled with AluI restriction enzyme to successfully identify donkey and horse species in halal food. In addition, cattle-buffalo and sheep-goat (Girish et al., 2005), cattle, yak, and buffalo (Chen et al., 2010), swine and wild boar (Mutalib et al., 2012), and chicken, beef, and sheep meat (Kušec et al., 2017) have also been successfully differentiated by using PCR-RFLP technologies. Furthermore, our present study also confirmed that the PCR- RFLP method was successful in detecting meat adulteration in products that had undergone processing and cooking. Cooking involving high temperatures and addition of several spices and condiments may lead to low DNA concentrations (Sakalar et al., 2012). Cooking of meat admixes in the current study affected RFLP by increasing its banding pattern in 12sr RNA and 16sr RNA while decreased in cytochrome gene using AluI and HinfI enzymes. Thus, the results support the conventional PCRRFLP method to detect meat adulteration on the basis of its sensitivity, efficiency, especially for high scales of production.

\section{CONCLUSIONS AND RECOMMENDATIONS}

Mitochondrial conserved genes 12S rRNA, 16S rRNA and Cyt- $b$ provide the reliability of PCR-RFLP method for distinguishing different species in meat mixtures.

\section{ACKNOWLEDGMENTS}

The authors declare that there are no sources of funding to be acknowledged.

\section{NOVELTY STATEMENT}

Meat adulteration is widespread and leads to serious public health risks and religious violations. DNA-based methods for meat authentication have proved to be accurate, fast and sensitive method. In the present study, PCR-RFLP technique with universal primers for mitochondrial $12 \mathrm{~S}$ rRNA, 16S rRNA and Cyt-b genes was performed on DNA from Beef, donkey, dog, poultry, and MDM in various combinations with different percentage up to $5 \%$ concentration of admix meat in row and cooked mixture. All species and mixtures at different ratios could be discriminated using AluI and HinfI restriction enzymes giving rise to distinct banding patterns. The physical effect of heat treatment (cooking) exerted during meat processing influenced the banding number, thus mitochondrial $12 \mathrm{~S}$ rRNA, 16S rRNA, and Cyt-b genes using PCR-RFLP method could be used for identification of meat mixtures.

\section{AUTHOR'S CONTRIBUTION}

All authors contributed equally.

\section{CONFLICT OF INTEREST}

The authors have declared no conflict of interest. 


\section{REFERENCES}

-Ali ME, Hashim U, Mustafa S, Che Man YB (2011). Swinespecific PCR-RFLP assay targeting mitochondrial cytochrome $\mathrm{b}$ gene for semi-quantitative detection of pork in commercial meat products. Food Anal. Methods, https:// doi.org/10.1007/s12161-011-9290-5

-Amaral J, Meira L, Oliveira MBPP, Mafra I (2016). Advances in authenticity testing for meat speciation. Advances in food authenticity testing, Woodhead Publishing. pp. 369-414. https://doi.org/10.1016/B978-0-08-100220-9.00014-X

- Chen A, Wei C, Chen G, Zhao Y, Yang S (2015). Duplex PCR approach for the detection and quantification of donkey, horse and mule in raw and heat-processed meat products. Int. J. Food Sci. Technol., 50: 834-839. https://doi.org/10.1111/ ijfs. 12720

- Chen SY, Liu YP, Yao YG (2010). Species authentication of commercial beef jerky based on PCR-RFLP analysis of the mitochondrial 12S rRNA gene. J. Genet. Genom., 37: 763769. https://doi.org/10.1016/S1673-8527(09)60093-X

-Doosti A, Dehkordi PG, Rahimi E (2014). Molecular assay to fraud identification of meat products. J. Food Sci. Technol., 51: 148-152. https://doi.org/, https://doi.org/10.1007/ s13197-011-0456-3

-Downey G (2016). Advances in food authenticity testing. Improving quality throughout the food chain. Woodhead Publishing.

-El-Sheikha AF, Levin RE, Xu J (2018). Molecular techniques in food biology: Safety, biotechnology, authenticity and traceability ( $1^{\text {st }}$ Ed.). Hoboken, NJ: John Wiley and Sons. https://doi.org/10.1002/9781119374633

-Erwanto Y, Abidin MZ, Sugiyono EY, Rohman A (2014). Identification of pork contamination in meatballs of Indonesia local market using polymerase chain reactionrestriction fragment length polymorphism (PCR-RFLP) analysis. Asian Aust. J. Anim. Sci., 27(10): 1487-1492. https://doi.org/10.5713/ajas.2014.14014

- Fajardo V, González I, Martín I, Rojas M, García T, Martín R (2010). A review of current PCR-based methodologies for the authentication of meats from game animal species. Trends Food Sci. Technol., 21: 408-421. https://doi. org/10.1016/j.tifs.2010.06.002

-FAO (2018). Gateway to poultry production and products. http://www.fao.org/poultryproduction-products/ production/poultry-species/en/

- Girish PS,Anjaneyulu ASR, Viswas KN,Shivakumar BM,Anand M, Patel M, Sharma B (2005). Meat species identification by polymerase chain reaction-restriction fragment length polymorphism (PCR-RFLP) of mitochondrial 12S rRNA gene. Meat Sci., 70(1): 107-112. https://doi.org/10.1016/j. meatsci.2004.12.004

- Gvozdanović K, Kušec ID, Margeta P, Salajpal K, Džijan S, Bošnjak Z, Kušec G (2020). Multiallelic marker system for traceability of Black Slavonian pig meat. Food Contr., 109: 106917. https://doi.org/10.1016/j.foodcont.2019.106917

- Hrbek V, Zdenkova K, Jilkova D, Cermakova E, Jiru M, Demnerova K, Pulkrabova J, Hajslova J (2020). Authentication of meat and meat products using triacylglycerols profiling and by DNA analysis. Foods, 9: 1269. https://doi.org/10.3390/foods 9091269

- Huang X, Zhou X, Lin Q, Fang W, Chen X (2013). PCR-RFLP technique for species identification of molted feathers in six species of co-occurring Ardeids. Conserv. Genet. Resour.,

5(3): 817-819. https://doi.org/10.1007/s12686-013-9916-6

-Kim Mi-Ju, Man S-S, Yeon K-S, Qin-Pei, Rae K-H, Yeong $\mathrm{K}-\mathrm{H}$ (2020). Development of a real time PCR assay for the detection of donkey (Equus asinus) meat in meat mixtures treated under different processing conditions. Foods, 9: 130. www.mdpi.com/journal/foods, https://doi.org/10.3390/ foods 9020130

- Kumar A, Kumar RR, Sharma BD, Gokulakrishnan P, Mendiratta SK, Sharma D (2015). Identification of species origin of meat and meat products on the DNA basis: A review. Crit. Rev. Food Sci. Nutr., 55: 1340-1351. https:// doi.org/10.1080/10408398.2012.693978

-Kušec ID, Samac D, Marget V, Radišić Ž, Vincek D, Kušec G (2017). Efficiency of PCR-RFLP and species-specific PCR for the identification of meat origin in dry sausages. Czech J. Food Sci., 35: 386-391.https://doi.org/10.17221/243/2016CJFS

- Masole C, Mphothwe GK, Moreki JC (2015). Value chain analysis of Botswana poultry industry: The case of Gaborone, Kgatleng, Kweneng and south east districts. J. World's Poult. Res., 5(3): 64-72.

- Moore JC (2011). Food fraud: Public health threats and the need for new analytical detection approaches. Food security: Intersect. Sustain. Saf. Defense, Natl. Agric. Biotechnol. Council Rep., 23: 209-220 (book). https://creativecommons. org/licenses/by-nc-nd/4.0/

-Mousavi SM, Khaniki GJ, Eskandari S, Rabiei M, Samiee SM, Mehdizadeh M (2015). Applicability of species-specific polymerase chain reaction for fraud identification in raw ground meat commercially sold in Iran. J. Food Compos. Anal., 40: 47-51. https://doi.org/10.1016/j.jfca.2014.12.009

-Murugaiah C, A1-Talib H, Radu S (2015). Forensics: Food authentication using MtDNA. J. Nutr. Health Food Sci., 3: 1-10. https://doi.org/10.15226/jnhfs.2015.00153

-Murugaiah C, Mohd N, Zainon, Mastakim M, Bilung ML, Selamat J, Radu S (2009). Meat species identification and halal authentication analysis using mitochondrial DNA. Meat Sci., 83: 57-61. https://doi.org/10.1016/j. meatsci.2009.03.015

- Mutalib SA, Nazri WSW, Shahimi S, Yaakob N, Sani NA, Abdullah A, Abd-Ghani M (2012). Comparison between pork and wild boar meat (Sus scrofa) by polymerase chain reaction-restriction fragment length polymorphism (PCRRFLP). Sains Malays., 41: 199-204.

- Prado M, Franco CM, Fente CA, Cepeda A, Vázquez BI, Velázquez JB (2002). Comparison of extraction methods for the recovery, amplification and species-specific analysis of DNA from bone and bone meals. Electrophoresis, 23: 1005-1012. https://doi.org/10.1002/15222683(200204)23:7/8<1005::AID-ELPS1005>3.0.CO;2-1

- Rahman MM, Ali ME, Hamid SBA, Bhassu S, Mustafa S, Al-Amin M, Razzak MA (2015). Lab-ona-chip PCRRFLP assay for the detection of canine DNA in burger formulations. Food Anal. Methods, 8: 1598-1606. https:// doi.org/10.1007/s12161-015-0090-1

- Rashid NR, Ali ME, Hamid SB, Rahman MM, Razzak MA, Asing, Amin MA (2015). A suitable method for the detection of a potential fraud of bringing macaque monkey meat into the food chain. Food Addit. Contamin. Part A, 32: 1013-1022. https://doi.org/10.1080/19440049.2015.10 39073

- Saikia DP, Kalita DJ, Borah P, Sarma S, Dutta R, Rajkhowa D (2016). Molecular characterization of the mitochondrial 16S 
rRNA gene of cattle, buffalo and yak. Veterinarski Arhiv 86 (6), 777-785.

- Sajali N, Wong SC, Abu BS, Mokhtar NFK, Manaf YN, Yuswan MH, Desa MNM (2021). Analytical approaches of meat authentication in food. Int. J. Food Sci. Technol., 56: 1535-1543. https://doi.org/10.1111/ijfs.14797

- Sakalar E, Abasiyanik MF, Bektik E, Tayyrov A (2012). Effect of heat processing on DNA quantification of meat species. J. Food Sci., 77(9): 40-44. https://doi.org/10.1111/j.17503841.2012.02853.x

-Soman M, Paul RJ, Antony M, Soumya PS (2020). Detecting mislabelling in meat products using PCR-FINS. J. Food Sci. Technol., 57(11): 4286-4292. https://doi.org/10.1007/ s13197-020-04641-w

- Spink J, Bedard B, Keogh J, Moyer DC, Scimeca J, Vasan A (2019a). International survey of food fraud and related terminology: Preliminary results and discussion. J. Food Sci.,

84: 2705-2718. https://doi.org/10.1111/1750-3841.14705

- Spink J, Embarek PB, Savelli CJ, Bradshaw A (2019b). Global perspectives on food fraud: Results from a WHO survey of members of the international food safety authorities network (INFOSAN). NPJ Sci. Food, 3(1): 12. https://doi. org/10.1038/s41538-019-0044-x

-Tian Z,Du J, YangJ,Liu A, Liu X, Liu G, Yin H (2015). A PCRRFLP Assay targeting RPS8 gene for the discrimination between bovine Babesia and Theileria species in China. Parasit. Vectors, 8(1): 475. https://doi.org/10.1186/s13071015-1085-x

-Tonder Ev (2020). Poultry MDM: Notes on composition and functionality, Earthworm express. Nose, 5 July 2020.

-Zheng X, Li Y,Wei W, Peng Y (2019). Detection of adulteration with duck meat in minced lamb meat by using visible nearinfrared hyperspectral imaging. Meat Sci., 149: 55-62. https://doi.org/10.1016/j.meatsci.2018.11.005 